\title{
Effects of Trophic Poisoning with Methylmercury on the Appetitive Elements of the Agonistic Sequence in Fighting-Fish (Betta Splendens)
}

\author{
Amauri Gouveia Jr. ${ }^{1,2}$, Caio Maximino de Oliveira², Cynthia Ferreira Romão², \\ Thiago Marques de Brito $^{2}$, and Dora Fix Ventura ${ }^{3}$ \\ ${ }^{1}$ Universidade Federal do Pará \\ ${ }^{2}$ Universidade Estadual Paulista, Bauru \\ ${ }^{3}$ Universidade de São Paulo
}

The aggressive display in Betta splendens is particularly prominent, and vital to its adaptation to the environment. Methylmercury is an organic variation of $\mathrm{Hg}$ that presents particularly pronounced neuro-behavioral effects. The present experiments aim to test the effect of acute and chronic poisoning with methylmercury on the display in Bettas. The animals were poisoned by trophic means in both experiments ( $16 \mathrm{ug} / \mathrm{kg}$ in acute poisoning; $16 \mathrm{ug} / \mathrm{kg} / \mathrm{day}$ for chronic poisoning), and tested in agonistic pairs. The total frequency of the display was recorded, analyzing the topography of the agonistic response. The methylmercury seems to present a dose- and detoxification-dependent effect on these responses, with a more pronounced effect on motivity in acute poisoning and on emotionality in the chronic poisoning. It is possible that this effect could be mediated by alteration in the mono-amino-oxidase systems.

Keywords: methylmercury, aggression, emotional behavior, Betta splendens

\begin{abstract}
El despliegue agresivo en la Betta splendens es especialmente prominente y es vital para su adaptación al medio ambiente. Metil-mercurio es una variación orgánica de $\mathrm{Hg}$ que presenta efectos neuro-conductuales especialmente pronunciados. Los experimentos actuales intentan poner aprueba el efecto de envenenamiento agudo y crónico con metil-mercurio sobre el despliegue en Bettas. Los animales fueron envenenados tróficamente en ambos experimentos (16 ug/ $/ \mathrm{kg} \mathrm{e}$ el envenenamiento agudo) y probados en parejas agonistas. Se registró la frecuencia total del despliegue, analizando la topografía de la respuesta agonista. El metil-mercurio parece presentar un efecto dependiente de la dosis y de la detoxificación sobre estas respuestas, con un efecto más pronunciado sobre la motilidad en el envenenamiento agudo y sobre la emotividad en el envenenamiento crónico. Posiblemente, este efecto podría mediarse por la alteración en los sistemas de mono-amino-oxidasa.
\end{abstract}

Palabras clave: metil-mercurio, agresión, conducta emocional, Betta splendens

Correspondence concerning this article should be addressed to Amauri Gouveia Jr., Departamento de Fisiologia, Centro de Ciências Biológicas, UFPA/Campus Guamá - r., Belém - PA, Brazil. E-mail: agjunior@ufpa.br 
The aggressive display of the Betta splendens (Teleostei, Belontiidae) is very prominent, and Bronstein (1980, 1981a, 1982) suggested that it's reproductive and agonistic strategies are typical of many teleosts that utilize external fertilization in relation to the body of the female of the species. A speciesspecific agonistic sequence may be separated into appetitive, mating, and post-mating components (Klein, Figler, \& Peeke, 1976). In the case of Betta splendens, the appetitive component that corresponds to the display has been the most studied. These appetitive components include saturation of body coloration, erection of the opercles, or gill cover, orientation and movement characteristics (Simpson, 1968). The mating-related components include biting, jaw blocking between opponents and striking with the tail (Simpson, 1968). An alteration in one of the appetitive components predictably alters the mating components (Klein, Figler, \& Peeke, 1976; Bronstein, 1985).

The response to the display may be elicited by (a) the presentation of a subject of the same species in the same or another aquarium, (b) the presentation of a model, or (c) the presentation of a mirror (Meliska, Meliska, \& Peeke, 1980). The vigor with which animals present their display, defined by the duration and frequency of the demonstration, is a reliable predictor of the animal's performance in a real combat situation (Evans, 1985) and in situations in which dominance is established (Baenninger, 1968; Meliska \& Meliska, 1976; Meliska et al., 1975, 1980; Simpson, 1968). Rhoad, Kalat, and Lopfer (1975) showed that the agonistic display in Bettas is more vigorous when they are presented with a male of the same species, followed by a mirror image, a moving model, and finally, a stationary model.

In neural terms, the aggressive display of the Betta splendens was studied with ablation techniques and discrete lesions of the telencephalon (Marino-Neto \& Sabbatini, 1983a, 1983b) and through the waterborne presentation of neurotransmitters (Baenninger, 1968). Baenninger exposed various fighting-fish to epinephrine and norepinephrine hydrically and observed their agonistic display, revealing suppression of the appetitive elements of the agonistic sequence of the Betta. Electrolytic lesions in the dorsomedial telencenphalon (Marino-Neto \& Sabbatini, 1988; this region is probably homologous to the tetrapod amygdala: Braford Jr., 1995; Butler, 2000) appear to cause a decrease in the frequency and duration of various behaviors of the display and a greater stereotypy in the patterns of the display. Beyond this, the agonistic sequences are more dispersed among other behaviors, such as exploration and locomotion, with sudden returns to aggressive activity (Marino-Neto \& Sabbatini, 1983a). The subjects' responses to mechanical stimuli applied to the wall of the aquarium were also altered, with an increase in jumps or "fast starts" and with a more rapid frequency in respect to these stimuli (Marino-Neto \& Sabbatini, 1983b). Taken together, these results suggest that the dorsomedial telencephalon of the Betta splendens plays an important role in inhibitory control of the animal's attention and excitation system (cf. Flood et al., 1976, for a discussion of the function of the telencephalon of teleosts in attention and excitation). The other element altered by lesions of the dorsomedial telencephalon is the gradual inhibition of behavior after accustomization. Portavella et al.'s work (Portavella, Vargas, Torres, \& Salas, 2002), using injuries to the dorsomedial telencephalon of the Carassius auratus, showed that emotional learning (inhibitory avoidance) is controlled by this structure. Thus, it is possible that the dorsomedial telencephalon is a necessary structure for the control of aggression and learning of avoidance in teleosts, functionally analogous to the amygdala in tetrapods (cf. Panksepp, 1998). This functional analog could, perhaps, be supported by a de facto homology of the structures (Bradford, 1995; Butler, 2000; Northcutt, 2006). In fact, the connection between aggression and anxiety has been made in various models (i.e., Miczek, Weerts, Vivian, \& Barros, 1995) and, apparently, both are controlled by the serotoninergic system (Graeff, 2002). The serotoninergic neural systems exhibit consistency in the evolutionary chain of medial structures (Ma, 1997). The function of the serotoninergic systems was observed in the mediation of the aggressive response in species that included lobsters, ants, fish, and rodents (Berman, Tracy, \& Coccaro, 1997; Blanchard, Griebel, Rodgers, \& Blanchard, 1998; Lesch \& Merschdorf, 2000).

Methylmercury (abbreviated as $\mathrm{MeHg}$ or $\mathrm{CH}_{3} \mathrm{Hg}$ ) is a highly toxic and bioaccumulative metal, with a profound effect on the nervous system, as much in humans as in other animals (Hartman, 1995). Mercury has been released in nature in an uncontrolled manner, principally through gold panning, and chlorine, caustic soda, and paper industries, among others. Fish, at the top of the food chain, appear to be the most affected by aquatic contamination (Azevedo, 2003). It has been demonstrated that organic and inorganic mercury deposits cause extensive effects on the central nervous system in fish of the teleost order (Baatrup, 1991). Methylmercury is present in great bioaccumulation in the aquatic environment (Azevedo, 2003), and trophic and hydric exposure are likely the greatest route of accumulation of mercury in fish (Harris \& Bodaly, 1998; Regine, Gilles, Yannick, Alain, 2006). Although various studies have been conducted on the lethality of mercury, the neurotoxicology of methylmercury in sublethal doses is of interest from an ecological point of view, as the substance presents alterations that have a great effect on the reproductive capacity and survival of animals in the natural environment.

Few behavioral studies have been conducted using fish as models. In general, Methylmercury appears to affect swimming performance, learning, patterns of activity, and the abilities of foraging, reproduction, competition, and avoidance of predators in fish (e.g., Atchison, Henry, \& Sandheinrich, 1987; Baatrup, 1991; Bernstssen, Aatland, \& Handyc, 2003; Fjeld, Haugoen \& Vlestad, 1998; Webber \& Haines, 2003; Woebser, 1975). These consequences, in general, have effects on the likelihood of survival and reproductive ability of fish populations in the natural environment. 
Concern over the neurobehavioral effects of methylmercury arose from reports of contamination in humans. In general, various symptoms of the effects on the central nervous system were reported. According to Azevedo (2003), ataxia (loss of coordination) is the first clinical indication of methylmercury contamination, but paresthesia, dysarthria, deafness, appearance of scotomas (blind spots), reduction of the visual field, blindness, alterations in olfactory and palate function, emotional alterations, muscular tremors, and perturbations of movement are also included. In addition to these effects, apraxia, astereognosia, and disturbance of active sensation were detected. Ninomiya et al. (2005) considered that the persistent somatosensory effects immediately after exposure to methylmercury are induced by injuries spread throughout the somatosensory cortex. The effects on the emotional balance in contaminated patients is correlated in studies that indicate alterations in the response to predators in fish (Smith \& Weis, 1997), as well as in feeding behavior (Fjeld, Haugoen, \& Vlestad, 1998), as much in exposure in the embryonic stage as in adults. Studies in our laboratory indicated that mercury alters the response to anxiety as much in mice as in fish of the Danio rerio (zebra fish) species (unpublished data). Besides the data on Danio rerio, facilitating certain generalizations, these are not complete for other species of fish, given the diversity of metabolism encountered among this class of vertebrates, especially the variation encountered among tropical and nontropical fish, as tropical fish can exhibit physiological parameters very different from non-tropical fish.

In neurotoxicological terms, the effect of methylmercury has been described basically in mammals. Although it has been believed for a long time that absorption of methylmercury in the intracellular environment occurs through "molecular mimesis" (a process in which a given molecule is "confused" with another due to structural similarity), it has been shown (Hoffmeyer et al., 2006) that it is more likely that this process occurs through "mimesis" of the methylmercury molecule with the 1-alpha portion of an amino acid. Mercury causes depletion of the principal cellular antioxidants, with high affinity for the thionic group (Azevedo, 2003), the functional group of the amino acid, cysteine. Beyond effects on the retinal cell (eg, Bonci et al., 2006), various other cells of the nervous system appear to be affected by exposure to the metal (Nascimento \& Chasin, 2001). The observation that methylmercury induces oxidative stress in the brain of house mice (Yee \& Choi, 1994) led Aschner et al. $(1995,1998,2000)$ to consider that there are two critical components in the neurotoxicology of methylmercury: the increase in extracellular concentration of glutamate as a result of alterations in the astrocyte function (Aschner, Vitarella, Allen, Conklin, \& Cowan, 1998), as well as direct interaction with the cysteine transporter, causing a decrease in the concentration of cysteine for synthesis of glutathione; and interference with the function of the astrocyte transporter of glutamate, causing an increase in the extracellular concentration of this neurotransmitter (Morken, Sonnewald, Aschner, \& Syversen, 2005); this activity is modulated by adenosine (Aschner, Mullaney, Wagoner, Jr., Lash, \& Kimelberg, 1995) and by glutathione (Kaur, Aschner, \& Syversen, 2006). Moreover, the generation of species reactive to oxygen, a consequence of the altered production of arachidonic acid, must interfere with the removal of extracellular glutamate, inhibiting the activity of glutamate transporters. According to Juárez et al. (2005), altered activity of NMDA receptors may contribute to a sudden increase in the apoptosis of various cortical and subcortical cells. Allen et al. (Allen, El-Oqayli, Aschner, Syversen, \& Sonnewald, 2001) claimed that the effect of methylmercury on the activity of astrocytes is mediated by the effect of this toxin on the mitochondria of the astroglia. In addition to glutamate, various other neurotransmitter systems were implicated in the neurotoxicology of mercury: muscarine and nicotine receptors (Bondy \& Agrawal, 1980; Castoldi, Candura, Costa, Manzo, \& Costa, 1996), nitric oxide (Kuo, Huang, \& Lin-Shiau, 2002) serotoninergic (Hrdina, Peters, \& Singhal, 1976), noradrenergic (Komulainen \& Tuomisto, 1981; Gassó, Suñol, Sanfeliu, Rodríguez-Farré, \& Cristòfol, 2000) and dopaminergic (Bondy \& Agrawal; Komulainen \& Tuomisto; Scheuhammer \& Cherian, 1985; Faro et al., 1997, 2002; Daré et al., 2003) systems. The activity of monoamino-oxidase (MAO) also exhibits extensive alterations due to methylmercury toxicology (Chakrabarti et al., 1998). MAO inhibition by methylmercury is involved in the accumulation of serotonin in the nervous system and a decrease in the level of 5-hydroxi-indolacetic acid (Azevedo, 2003). According to Fonfría, Rodríguez-Farré, and Suñol (2001), a good part of the effects of methylmercury on neurotransmission can be explained in terms of the affinity between this toxin and the thiol group of proteins, peptides, and amino acids. Methylmercury also alters intracellular concentrations of $\mathrm{Ca}^{2+}$ in neuroblastomas that express the 5$\mathrm{HT}_{3}$ receptor (Hare \& Atchison, 1995a), which led Hare and Atchison (1995b) to claim that methylmercury depolarizes the plasmatic membrane of these cells, causing an increase in the activation of the $\mathrm{Na}^{+}$and $\mathrm{Ca}^{2+}$ channels; Tarabova et al. (2006) observed that methylmercury inhibits the expression of the Cav3.1 of neuronal cells in the HEK 293 family. The sensitivity of the potassium channels to methylmercury is low (Yuan et al., 2005), in contrast to the extensive alteration of the calcium dynamics. Furthermore, Girault, Boudou, and Dufourc (1997) reported that methylmercury is connected to lipids in the cellular membrane, inducing a great number of disturbances in its structure. The temporal course of these neurotoxicological alterations by methylmercury is of some importance: the first effect to appear is the formation of an oxygen reactive species, followed by oxidative damage to the DNA, parallel to partial depolarization of the mitochondria (Belletti et. al., 2002). Given an alteration so pervasive on molecular systems, it is difficult to determine a general effect of mercury on any species, or, specifically, species of various phyla. 
The present study aims at verifying the effect of trophic methylmercury poisoning on the agonistic display of the Betta splendens. Given that the aggressive elements are probably mediated by the same structures that control emotion, the results will be discussed in the light of the literature on the emotional effects of mercury and other studies conducted in our laboratory.

Experiment 1: Effects of purification of acute poisoning on the display in Betta splendens

\section{Method}

\section{Subjects}

Twelve adult Bettas (Aqua Mundi, Bauru/SP) were used for this experiment, experimentally ingenuous, kept isolated in individual tanks $(14 \times 6 \times 11 \mathrm{~cm})$, with controlled lighting (12/12 hrs, cycle beginning at 7:00 a.m.), average $\mathrm{Ph}$ level at 8.0 and average temperature of $22^{\circ} \mathrm{C}$. The subjects weighed $0.6 \pm 0.05 \mathrm{mg}$.

The animals were kept previously in the laboratory for 15 to 30 days, until they were acclimated and adapted to the dietary regime, which during this time was composed of flocculated rations (Mini Betta, Brazil) and salt-water artemias.

The baseline of the subjects' display was obtained through observation of agonistic interactions, in separate aquariums, in daily sessions lasting 5 minutes. For this, two tanks were placed side by side, each of them containing a fish. The behaviors described in Table 1 were observed.

All behaviors were described in terms of frequency. The interactions were recorded, and the behaviors were transcribed using EthoLog software (Ottoni, 2000). Furthermore, an analysis of the duration of the entirety of the display was also made.

Table 1

Distinct Display Behaviors

Floating, without opening the fins

Resting at tank bottom

Emerging and swallowing air

Swimming slowly using pectoral fins

Undulating swimming pattern

"Shaking" the body

Opening the gill cover, without either horizontal or vertical

display

Horizontal display

Vertical display

Arching the body

Charging the opponent

Retreating from opponent when becoming the target of attack/advance
The fish in the "contaminated" group were trophically contaminated, by ingestion of saltwater artemias, hydrically contaminated for 24 hours, at the ratio of $0.2 \mathrm{~g}$ of artemia/gram of fish, resulting in an initial contamination of $0.4 \mu \mathrm{g}$ methylmercury/g /Betta. After a purification period (24, 48, and 96 hours), the fish were tested in agonistic pairs, in individual tanks adjacent to each other, the measures of the rate of occurrence of the behaviors were recorded in an ethogram of the complete display, determined above, of the molar components of the display (see results below) and the total activity (determined as the sum of the frequency of all of the behaviors).

\section{Results}

The results of the ethogram were analyzed at two levels: in terms of the frequency of the behaviors in Table 1, and total activity; and in a larger group, determined by factor analysis (principal components and varimax rotation with Kaiser normalization). The extraction of principal components reached rotation convergence at 6 iterations, generating three main extracted components. Table 2 and Figure 1 show the results of the analysis.

The first extracted components contains the behaviors of floating, resting at the bottom, breathing, shaking, arching, charging, and retreating, being, therefore, a component of the accessory elements of the display; the second components contains the behaviors of swimming with fins, undulating, and opening the gill covers, thus configuring a component of motility; the third components contains the behaviors of horizontal and vertical display, configuring the component of the display itself. These results corroborate the molar analysis of the literature (e.g., Bronstein, 1984). Figures 2 and 3 present the means and standard-deviations for the two levels of the analysis.

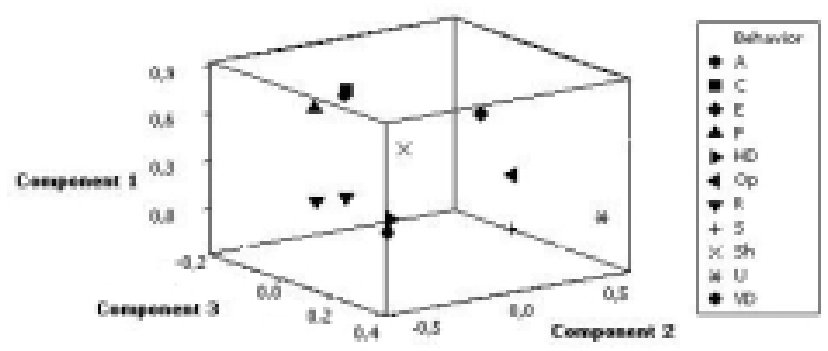

Figure 1. Rotated vectorial space of the components extracted with principal components.

Key: F: floating; R: resting at tank bottom; E: emerging and swallowing air; S: swimming slowly with pectoral fins; U: undulating swimming pattern; Sh: "shaking" the body; Op: opening gill cover; HD: horizontal display; VD: vertical display; A: arching body; C: charging; R: retreating. 
Table 2

Rotated Component Matrix (Elements in Boldface are the Behaviors Belonging to that Component)

\begin{tabular}{lccr}
\hline & \multicolumn{2}{c}{ Components } \\
\cline { 2 - 4 } Behaviors & 1 & 2 & $-3.515^{-3}$ \\
\hline Floating & $\mathbf{0 . 7 5 9}$ & $5.768^{-2}$ \\
Resting at tank bottom & $\mathbf{0 . 1 6 8}$ & -0.365 & $-5.579^{-2}$ \\
Emerging and swallowing air & $\mathbf{0 . 5 3 3}$ & 0.524 & 0.201 \\
Swimming slowly with pectoral fins & -0.224 & $\mathbf{0 . 6 7 8}$ & 0.348 \\
Undulating swimming pattern & $3.059^{-2}$ & $\mathbf{0 . 7 0 2}$ & -0.188 \\
Shaking the body & $\mathbf{0 . 3 9 5}$ & 0.111 & -0.303 \\
Opening gill cover & 0.113 & $\mathbf{0 . 6 8 4}$ & $\mathbf{0 . 8 1 7}$ \\
Horizontal display & $-3.469^{-2}$ & $4.809^{-2}$ & $\mathbf{0 . 7 6 0}$ \\
Vertical display & -0.106 & $2.225^{-2}$ & $7.677^{-2}$ \\
Arching body & $\mathbf{0 . 8 0 9}$ & -0.201 & -0.260 \\
Charging & $\mathbf{0 . 6 1 9}$ & 0.146 & $3.093^{-2}$ \\
Retreating & 0.16 & -0.191 & \\
\hline
\end{tabular}

Note. Component 1 = accessory elements of display; Component $2=$ motility component; Component $3=$ display proper.

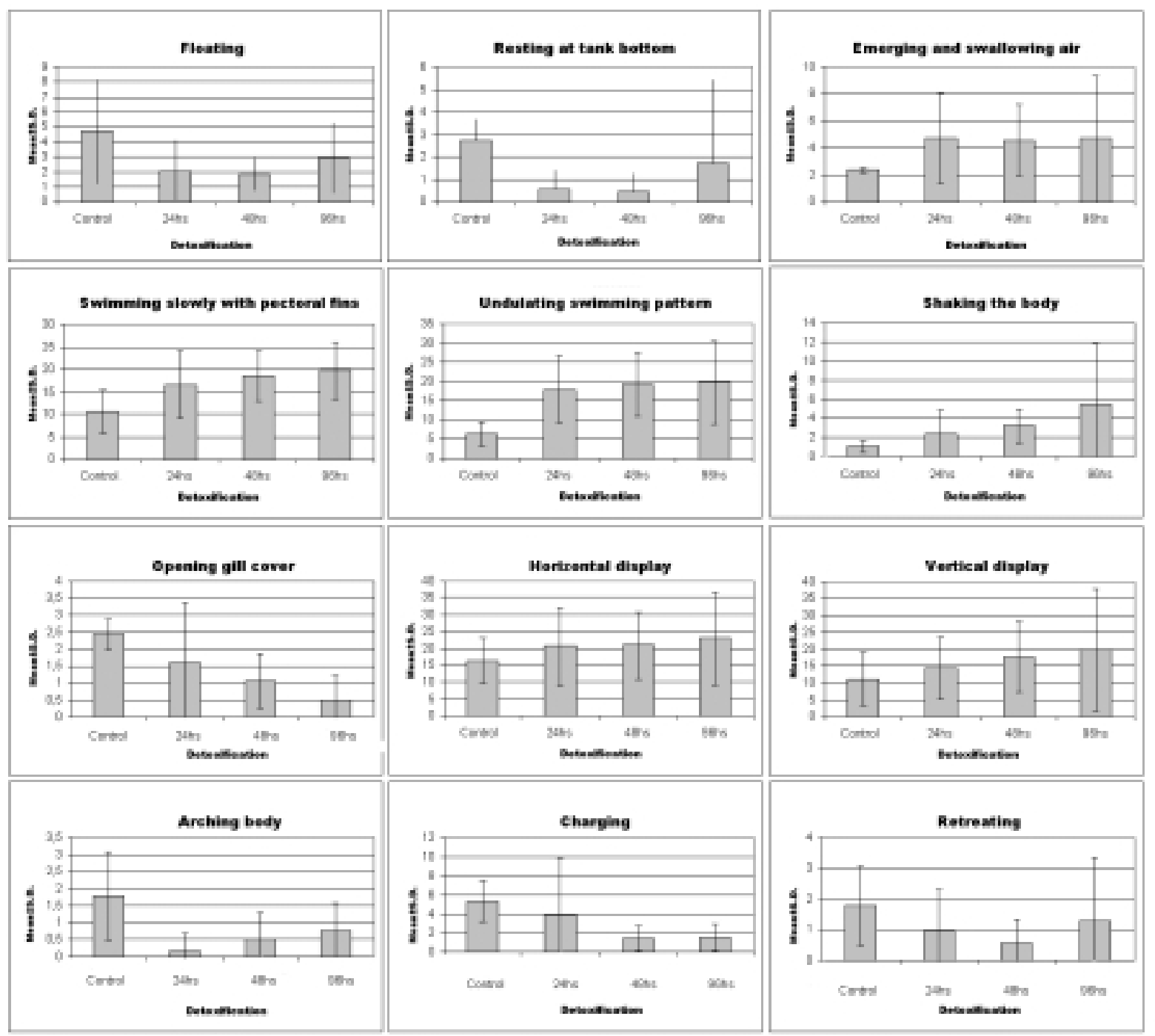

Figure 2. Frequencies $(M \pm S D)$ of the behaviors observed as a function of the detoxification time in acute poisoning. 


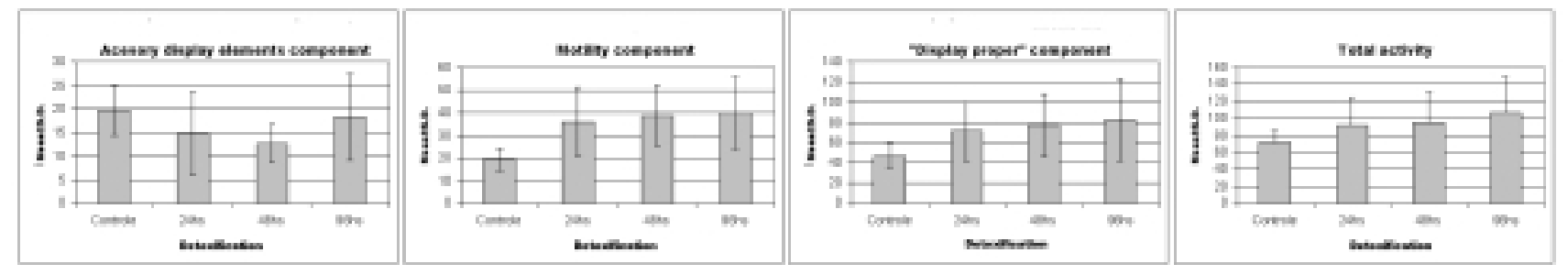

Figure 3. Frequencies $(M \pm S D)$ of the behaviors grouped by components of the factor analysis and of total activity in acute poisoning, as a function of detoxification time. The results of the factor analysis are found in Table 2 and Figure 1.

Table 3

Matrix of the Difference for the Independent Variable "Purification"

\begin{tabular}{|c|c|c|c|c|c|}
\hline Dependent variable & Treatment & Treatment & Mean difference & Standard error & Significance \\
\hline \multirow{2}{*}{ Floating } & \multirow{2}{*}{ Control } & 24 Hours & 2.585 & 0.808 & .011 \\
\hline & & 48 Hours & 2.863 & 0.808 & .004 \\
\hline \multirow{2}{*}{ Resting at tank bottom } & \multirow{2}{*}{ Control } & 24 Hours & 2.184 & 0.676 & .010 \\
\hline & & 48 Hours & 2.295 & 0.676 & .006 \\
\hline \multirow{3}{*}{ Swimming slowly with pectoral fins } & \multirow{3}{*}{ Control } & 24 Hours & -6.085 & 2.036 & .020 \\
\hline & & 48 Hours & -7.973 & 2.036 & .001 \\
\hline & & 96 Hours & -9.196 & 2.036 & $<.001$ \\
\hline \multirow{3}{*}{ Undulating swimming pattern } & \multirow{3}{*}{ Control } & 24 Hours & -11.405 & 2.750 & $<.001$ \\
\hline & & 48 Hours & -12.682 & 2.750 & $<.001$ \\
\hline & & 96 Hours & -13.238 & 2.750 & $<.001$ \\
\hline Shaking the body & Control & 96 Hours & -4.310 & $1, .83$ & .003 \\
\hline \multirow{3}{*}{ Opening gill cover } & \multirow{3}{*}{ Control } & 48 Hours & 1.379 & 0.350 & .001 \\
\hline & & 96 Hours & 1.934 & 0.350 & .000 \\
\hline & & 96 Hours & 1.111 & 0.350 & .012 \\
\hline \multirow{3}{*}{ Arching body } & \multirow{3}{*}{ Control } & 24 Hours & 1.608 & 0.377 & $<.001$ \\
\hline & & 48 Hours & 1.274 & 0.377 & .006 \\
\hline & & 96 Hours & 0.997 & 0.377 & .049 \\
\hline \multirow{2}{*}{ Charging } & \multirow{2}{*}{ Control } & 48 Hours & 3.821 & 1.096 & .005 \\
\hline & & 96 Hours & 3.765 & 1.096 & .005 \\
\hline Total activity & Control & 96 Hours & -34.267 & 11.152 & .016 \\
\hline Component 1 & Control & 48 Hours & 7.176 & 2.404 & .020 \\
\hline \multirow{3}{*}{ Component 2} & \multirow{3}{*}{ Control } & 24 Hours & -16.666 & 4.350 & .002 \\
\hline & & 48 Hours & -19.277 & 4.350 & $<.001$ \\
\hline & & 96 Hours & -20.499 & 4.350 & $<.001$ \\
\hline \multirow{2}{*}{ Component 3} & \multirow{2}{*}{ Control } & 48 Hours & -30.110 & 10.027 & .019 \\
\hline & & 96 Hours & -35.666 & 10.027 & .004 \\
\hline
\end{tabular}

Note. Only the treatments in which a significant statistical difference was observed are shown. 
Statistical analysis (one-way MANOVA, detoxification as inter-subject factor, type III sum of squares) revealed poisoning effects, mediated by detoxification from methylmercury, on the behaviors of floating, $F(89.769,3)=$ $5.096, p=.003$; resting on the tank bottom, $F(63.361,3)=$ $5.135, p=.003$; swimming with fins, $F(899.549,3)=8.04$, $\mathrm{p}<.001$; undulations, $F(2121.513,3)=10.3087$, p <.001; shaking, $F(177.651,3)=4.702, p=.005$; opening the gills, $F(36.775,3)=11.099, \mathrm{p},<.001 ;$ arching, $F(25.397,3)=$ $6.767, \mathrm{p}<.001$; charging, $F(188.922,3)=5.827, p=.001$; and total activity, $F(10972.043,3)=3.268, p=.026$. The MANOVA of the components of the factor analysis revealed effects on all of the components (Component 1: $F(583.483$, $3)=3.738, p=.015$; Component 2: $F(4916.596,3)=9.623$, $\mathrm{p}<.001$; Component 3: $F(13318.386,3)=4.907, p=.004)$.

The post-hoc tests carried out on the ANOVA indicated a detoxification-dependent effect from acute poisoning. Table 3 shows the delimited statistical differences from the posthoc test (Tukey's HSD) for the recorded variables.

\section{Discussion}

The present results appear to indicate, for acute poisoning, a detoxification-dependent effect from methylmercury only for the behavior of opening the gill covers. When the detoxification times are compared with each other for the other analyzed variables, we observe an effect from detoxification from the substance. Given that the central control of the gill cover opening is different from the rest of the behaviors (Gorlick, 1989), it is possible that methylmercury differentially affects the elements of the display. Additionally, with the dose studied, we did not observe effects on the horizontal and vertical display behaviors, even though this effect is observed when these behaviors are taken conjointly (molar analysis). These data present a more pronounced effect from methylmercury on Component 2 (the motility component). In fact, we observed a decrease in the detoxification-dependent decrease in motility (see Figure 2), less pronounced when we observed Component 3 (display proper). These data indicate a detoxification-dependent effect on motility and for emotional elements of aggression, with a greater effect on motility than on the emotional state.

\section{Experiment 2: Effects of chronic poisoning on the display in Betta splendens}

\section{Method}

\section{Subjects}

The subjects $(n=10)$ were subjected to the same conditions as those in Experiment 1. Upon completion of the period of acclimation and adaptation to the dietary regime, the the fish were submitted to definition of their base line, as in Experiment 1. After this phase, they were subjected to chronic, trophic poisoning by ingestion of salt-water artemias (Arthemia salina), previously contaminated hydrically with methylmercury at a dosage of $16 \mu \mathrm{g} / \mathrm{l}$, offering a dose of $1 \mathrm{~g}$ of artemia for each 30 $\mathrm{g}$ of fish on alternating days of collection, totaling 15 doses over a 35-day period. The subjects weighed $5.1 \pm 0.6 \mathrm{mg}$.

Data collection was alternated with the poisoning, so as to discriminate the effect of each dose cumulatively on the behavior of the fish. The subjects' baseline display was acquired through observation of agonistic interactions, in separate aquariums, in daily sessions lasting 5 minutes each. The same behaviors were observed as in Experiment 1. The interactions were recorded, and the behaviors were transcribed using EthoLog software (Ottoni, 2000). Furthermore, the duration of the entirety of the display was also analyzed.

\section{Results}

The same variables analyzed in Experiment 1 were analyzed with chronic poisoning. Figures 4 and 5 show the means ( \pm standard deviation) of the frequency of the occurrence of the behaviors.

The statistical analysis of the entire display (two-way MANOVA, poisoning factor with inter-subject factor, sum of squares type III) revealed effects from the poisoning on the behaviors of floating, $F(35.33,6)=2.98, p=.008$; breathing, $F(226.74,6)=2.83, p=.011$; swimming with pectoral fins, $F(277.60,6)=2.51, p=.023$; undulations, $F(1351.352,6)=3.208, p=.005$; opening the gill cover, $F(1315.039,6)=2.138, p=.051$; vertical display, $F(932.745,6)=2.503, p=.023$; arching, $F(169.699,6)$ $=11.075, p<.001$; and retreat, $F(83.951,6)=9.906, p$ $<.001$.

The post-test (Tukey's HSD) revealed statistically significant differences among the doses, as shown in the matrix of differences (see Table 4).

Analysis of the total activity (one-way ANOVA, poisoning dose as inter-subject factor, sum of squares type III) did not show statistically significant effects, $F(7284,6)$ $=1.79, p=.102$.

When the data were analyzed as a function of the behaviors clustered in components (see Figure 5), we observed the effects of the dose on the three components (Component 1: $F(4640.308,6)=4.148, p=.001$; Component 2: $F(6108.585,6)=3.390, p=.003$; Component 3: $F(2600.979,6)=2.711, p=.015$. The post-test (Tukey's HSD) revealed statistically significant differences among the doses. 

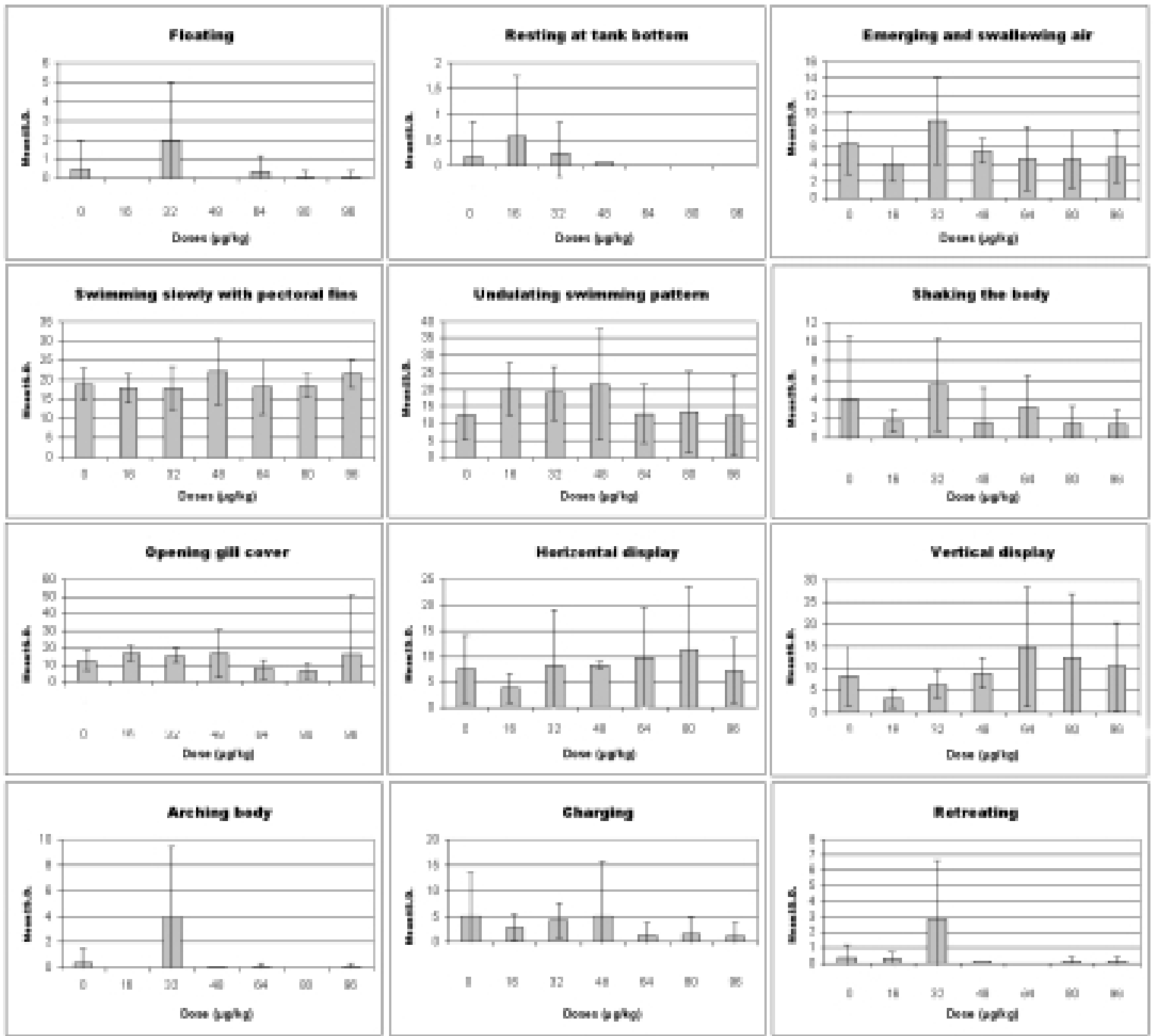

Figure 4. Frequencies $(M \pm S D)$ of the behaviors observed as a function of the dose applied in chronic poisoning. The behaviors are described in Table 1.

Table 4

Matrix of Differences among Doses, as a Function of Behavior

\begin{tabular}{lccccc}
\hline Dependent variable & Treatment & Treatment & Mean difference & Standard error & Significance \\
\hline & 0 & 32 & -1.41 & 0.41 & .01 \\
Floating & 32 & 48 & 1.92 & 0.56 & .01 \\
& & 80 & 1.84 & 0.56 & .02 \\
& & 96 & -1.84 & 0.56 & .02 \\
Emerging and swallowing air & 32 & 32 & 4.49 & 1.46 & .01 \\
Undulating swimming pattern & & 64 & 4.49 & 1.46 & .03 \\
Vertical display & 0 & 80 & -8.94 & 2.52 & .01 \\
Retreating & 16 & 48 & -11.75 & 3.94 & .05 \\
\hline
\end{tabular}




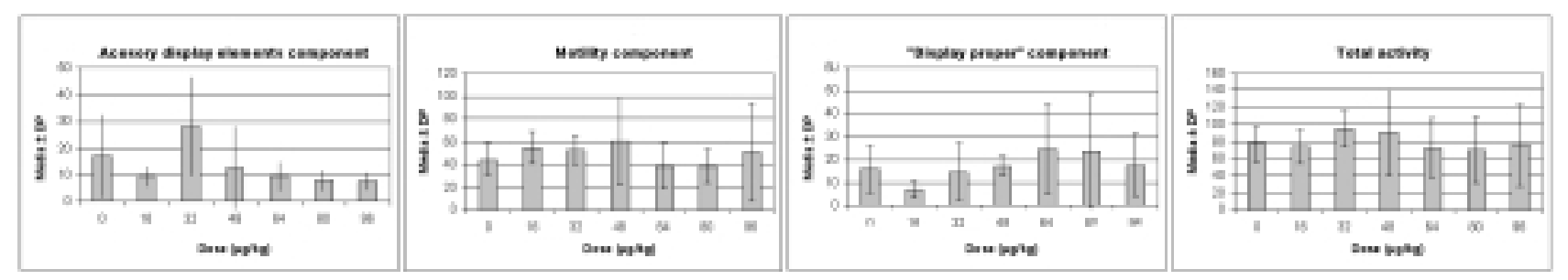

Figure 5. Frequencies $(M \pm S D)$ of the behaviors grouped by Components and by total activity in chronic poisoning, as a function of the dose used. The factor analysis is found in Table 2 and Figure 1.

Table 5

Matrix of Difference between Doses, as a Function of Behavior, Grouped in Components

\begin{tabular}{|c|c|c|c|c|c|}
\hline \multirow[b]{2}{*}{ Component 1} & \multicolumn{2}{|c|}{ Dose $(\mu \mathrm{g} / \mathrm{kg})$} & \multirow{2}{*}{$\begin{array}{c}\text { Difference } \\
-11.04\end{array}$} & \multirow{2}{*}{$\begin{array}{c}\text { Standard Error } \\
3.97\end{array}$} & \multirow{2}{*}{$\begin{array}{c}p \\
.08\end{array}$} \\
\hline & 0 & 32 & & & \\
\hline \multirow{5}{*}{ (Accessory display elements) } & 16 & 32 & -18.42 & 5.47 & .01 \\
\hline & 32 & 48 & -15.34 & 5.47 & .07 \\
\hline & & 64 & 18.42 & 5.47 & .01 \\
\hline & & 80 & 19.92 & 5.47 & .00 \\
\hline & & 96 & 20.26 & 5.47 & .00 \\
\hline Component 2 (Motility) & 0 & 48 & -16.44 & 5.22 & .03 \\
\hline \multirow[t]{2}{*}{ (Force) } & 48 & 64 & 22.17 & 7.07 & .03 \\
\hline & & 80 & 22.17 & 7.07 & .03 \\
\hline Component 3 (Display proper) & 16 & 64 & -17.42 & 5.16 & .01 \\
\hline (Display “specifically”) & & 80 & -16.75 & 5.16 & .02 \\
\hline
\end{tabular}

\section{Discussion}

These results appear to indicate, for chronic poisoning, a detoxification-dependent effect from methylmercury on various emotional parameters in Betta splendens. The fact that only the motor elements exhibit statistically significant differences in relation to control shows that the effect of $\mathrm{HgCH}_{3}$ (methylmercury), in these conditions, changes to a modulation of emotional elements, instead of, for example, motor, motivational, or cognitive elements. These results are compatible with the emotional effects of methylmercury on models of depression and anxiety in rats and fish, in other experiments conducted in our laboratory (unpublished data), and appear to emulate the emotional effect that is also found in poisoned human beings (cf. Hartman, 1995). The data also seem to indicate effects on the general tone of behavior, which may also be concurrent with metabolic alterations that are corollary to mercury poisoning (Castoldi, Coccini, Ceccatelli, \& Manzo, 2001; Harris \& Bodaly, 1998; Yasutake, Nakano, Miyamoto, \& Eto, 1997), as well as the emotional effects. Some hypotheses may be proposed about the neural basis of such an effect. The neural basis of the components of aggression in Betta splendens may be dissociated with motor and motivational components
(Gorlick, 1989; Marino-Netto \& Sabbatini, 1983b), and, as judged by the effects of LSD on the display (Arbit, 1957) as this drug exhibits a gross serotoninergic effect-it has a reasonable serotoninergic component (although further study is needed). As methylmercury appears to affect intracellular concentrations of calcium in neuroblastomas that express the $5-\mathrm{HT}_{3}$ receptor (Hare \& Atchison, 1995a) and the activity of monoamine-oxidase (Chakrabarti et al., 1998), it is possible that the emotional effect observed here, isolated from the motor effect, is due to these alterations in the serotoninergic dynamic. In zebra fish (Danio rerio), MAO expressed (Z-MAO) is sufficiently similar, in structural terms, to that encountered in mammals (Setini, Pierucci, Senatori, \& Nicotra, 2005).

\section{General Discussion}

The present experiment sought to analyze the effects of acute and chronic mercury poisoning on aggressive behavior in Betta splendens. Unlike the effect observed in acute poisoning, we observed a more gradual and "fine" effect in chronic mercury poisoning. We observed a differential effect in various components of the display, of a dose-dependent 
nature. Detoxification was not tested in chronic poisoning, as the behavioral tests were always conducted after 24 hours. On the other hand, acute intoxication shows a detoxificationdependent effect on more motor elements of the display. This result agrees with the literature (Royalty, Taylor, \& Korol, 1987; Bernstssen et al., 2003; Daré et al., 2003; Roegge et al., 2004), and may indicate a dopaminergic modulation from methylmercury. In fact, we can find references in the literature to effects from dopaminergic drugs on aggression in the Betta splendens (Baenninger, 1968) and other teleosts (Munro, 1986). The dose and detoxification dependent effects of methylmercury on the behavioral categories analyzed may depend on the amount of time elapsed from the mercury poisoning, which alters specific systems differently in relation to the time (e.g., Belletti et al., 2002).

The most detailed analysis of the elements of the display, taken in ungrouped behaviors, allows observation of this differential effect of methylmercury on motility, on the one hand, and emotional behavior, on the other. When we analyze the topography of the response, instead of using a more global category, we see more clearly an emotional modulation of the agonistic behavior of the Betta. This effect of methylmercury corroborates other findings in our laboratory (unpublished data), where we could observe doseand detoxification-dependent effects on the behavior of rats in the forced swim test (FST) and in the elevated plus-maze (see also Onishchenko et al., 2007), and of zebrafish in a dark/light preference model. These results reveal a possible effect on putative behavioral inhibition systems and behavioral approximation systems (e.g., McNaughton \& Corr, 2004), connected to defense reactions in mammals, as these systems are controlled by monoaminergic systems. As the distribution of mono-amines in the central nervous system of fish is very similar to that observed in mammals (Adrio, Anadón, \& Rodríguez-Moldes, 1999; Frankenhuisvan de Heuvel \& Nieuwenhuys, 1984; Kapsimali, Vidal, Gonzalez, Dufour, \& Vernier, 2000; Meek, Joosten, \& Hafmans, 2004; Ritchie, Livingston, Hughes, McAdoo, \& Leonard, 1983), indicating an evolutionary conservation of these systems, it is possible that the defense reactions are controlled by the same functions that appear in mammals. Thus, the emotional and motor alterations that were observed in this experiment indicate a possible effect of methylmercury on the biogenic amine systems that emotionally control defense behaviors.

In general, these results, along with the findings in the literature, present nested effects on various levels of the biological organization in fish (Weis, Smith, Zhou, SantiagoBass, \& Weis, 2001). At a neuro-chemical level, emotional effects can be interpreted from the viewpoint of the methylmercury effects on the monoamine oxidase system (Chakrabarti et al., 1998). In fact, whereas MAO-A has an effect on the serotoninergic system, MAO-A, as much as MAO-B, affect the central dopaminergic system (Westlund, Denney, Kochersperger, Rose, \& Abell, 1985). Thus, alteration of the function of the MAO system could affect emotional and motor components of behavior. Given that the monoamine oxidase is also found in astroglia, where it primarily has an effect on the metabolism of serotonin (Fitzgerald, Kaplinsky, \& Kimelberg, 1990), it is possible that the alteration of the monoamine oxidase system occurs in both types of cells, thus connecting the two neurotoxicological effects discussed in the literature. Meanwhile, the references in the literature about monoaminergic modulation of the display of the Betta splendens are different (cf. Arbit, 1957; Baenninger, 1968). All in all, it is likely that the behavioral effects, both motor and emotional, are due to an effect on the monoaminergic system of the poisoned subjects. As the display is essential for the behavioral ecology of the Betta splendens (Bronstein, 1980, 1981b), these behavioral alterations, at an organic level, can compromise the fitness of entire populations of contaminated animals. Given that methylmercury is bioaccumulative, this effect may also reverberate throughout the food chain.

\section{References}

Adrio, F., Anadón, R., \& Rodríguez-Moldes, I. (1999). Distribution of serotonin (5HT)-immunoreactive structures in the central nervous system of two chondrostean species (Acipenser baeri and Huso huso). Journal of Comparative Neurology, 407, 333-348.

Allen, J.W., El-Oqayli, H., Aschner, M., Syversen, T., \& Sonnewald, U. (2001). Methylmercury has a selective effect on mitochondria in cultured astrocytes in the presence of [U${ }^{13}$ C]glutamate. Brain Research, 908, 149-154.

Arbit, J. (1957). Effects of LSD-25 upon Betta splendens: A reliability of a bioassay technique. Journal of Appied. Physiology, 10, 317-318.

Aschner, M., Mullaney, K.J., Wagoner, Jr., D.E., Lash, L.H., \& Kimelberg, H.K. (1995). Adenosine modulates methylmercuric chloride $(\mathrm{MeHgCl}$ )-induced D-aspartate release from neonatal rat primary astrocyte cultures. Brain Research, 689, 1-8.

Aschner, M., Vitarella, D., Allen, J.W., Conklin, D.R., \& Cowan, K.S. (1998). Methylmercury-induced astrocytic swelling is associated with activation of the $\mathrm{Na}^{+} / \mathrm{H}^{+}$antiporter, and is fully reversed by amiloride. Brain Research, 799, 207-214.

Aschner, M., Yao, C.P., Allen, J.W., \& Tan, K.H. (2000). Methylmercury alters glutamate transport in astrocytes. Neurochemistry International, 37, 199-206.

Atchison, G.J., Henry, M.G., \& Sandheinrich, M. (1987). Effects of metals on fish behavior: A review. Environmental Biology of Fishes 18, 11-25.

Azevedo, F.A. (2003). Toxicologia do Mercúrio. São Carlos, São Paulo: Ed. Rima InterTox.

Baatrup, E. (1991). Structural and functional effects of heavy metals on the nervous system, including sense organs, of fish. Comparative Biochemistry and Physiology, 100, 253-257.

Baenninger, R. (1968). Catechol amines and social relations in Siamese fighting fish. Animal Behavior, 16, 442-447. 
Belletti, S., Orlandini, G., Vettoru, M.V., Mutti, A., Uggeri, J., Scandroglio, R., Alinov,i R., \& Gatti, R. (2002). Time course assessment of methylmercury effects on C6 glioma cells: Submicromolar concentrations induce oxidative DNA damage and apoptosis. Journal of Neuroscience Research, 70, 703-711.

Berman, M.E., Tracy, J.I., \& Coccaro, E.F. (1997). The serotonin hypothesis of aggression revisited. Clinical Psychology Review, 17, 651-665.

Bernstssen, M.H.G., Aatland, A., \& Handyc, R.D. (2003). Chronic dietary mercury exposure causes oxidative stress, brain lesions and altered behavior in Atlantic salmon (Salmo salar) parr. Aquatic Toxicology, 65, 55-72.

Blanchard D.C., \& Blanchard, R.J. (1978). Ethoexperimental Approaches to the Biology of Emotion. Annual Review of Psychology, 39, 43-68.

Blanchard, D.C., Griebel, G., Rodgers, R.J., \& Blanchard. R.J. (1998). Benzodiazepine and serotoninergic modulation of antipredator and conspecific defense. Neuroscience and Biobehavioral Reviews, 22, 597-612.

Bonci, D.M.O., de Lima, S.M.A., Grötzner, S.R., Oliveira Ribeiro, C.A., Hamassaki, D.E., \& Ventura, D.F. (2006). Losses of immunoreactive parvalbumin amacrine and immunoreactive protein kinase $\mathrm{C}$ bipolar cells caused by methylmercury chloride intoxication in the retine of the tropical fish Hoplias malabaricus. Brazilian Journal of Medical and Biological Research, 39, 405-410.

Bondy, S.C., \& Agrawa,l A.K. (1980). The inhibition of cerebral high affinity receptor sites by lead and mercury compounds. Archives of Toxicology, 46, 249-256.

Bradford Jr., M.R. (1995). Comparative aspects of forebrain organization in the ray-finned fishes: Touchstones or not? Brain, Behavior and Evolution, 46, 259-274.

Bronstein, P.M. (1980). Betta splendens: A territorial note. Bulletin of the Psychonomic Society, 16, 484-485.

Bronstein, P.M. (1981a). Commitments to aggression and nest sites in male Betta splendens. Journal of Comparative Physiology and Psychology, 95, 436-449.

Bronstein, P.M. (1981b). Social reinforcement in Betta splendens: A reconsideration. Journal of Comparative Physiology and Psychology. 95, 943-950.

Bronstein, P.M. (1982). Breeding, paternal behavior, and their interruption in Betta splendens. Animal Learning \& Behavior, 10, 145-151.

Bronstein, P.M. (1984). Agonistic and reproductive interactions in Betta splendens. Journal of Compatrative Psychology, 98, 421431.

Bronstein, P.M. (1985). Predictors of dominance in male Betta splendens. Journal of Comparative Psychology, 99, 47-55.

Butler, A.B. (2000). Topography and topology of the teleosts telencephalon: A paradox resolved. Neuroscience Letters, 293, 95-98.

Castoldi, A.F., Candura, S.M., Costa, P., Manzo, L., \& Costa, L.G. (1996). Interaction of mercury compounds with muscarinic receptor subtypes in the rat brain. Neurotoxicology, 17, 735742 .
Castoldi, A.F., Coccini, T,, Ceccatelli, S., \& Manzo, L. (2001). Neurotoxicity and molecular effects of methylmercury. Brain Research Buletin, 55, 197-203.

Chakrabarti, S.K,, Loua, K.M., Bai, C., Durham, H., \& Panisset, J-C. (1998). Modulation of monoamine oxidase activity in different brain regions and platelets following exposure of rats to methylmercury. Neurotoxicology and Teratology, 20, 161168.

Daré, E., Fetissov, S., Hökfelt, T., Hall, H., Ögren, S.O., \& Ceccatelli, S. (2003). Effects of prenatal exposure to methylmercury on dopamine-mediated locomotor activity and dopamine $\mathrm{D}_{2}$ receptor binding. Naunyn-Schmiedeberg's Archives of Pharmacology, 367, 500-508.

Evans, C.S. (1985). Display vigour and subsequent fight performance in the Siamese fighting fish, Betta splendens. Behavioral Processes 11, 113-121.

Faro, L.R.F., Durán, R., Nascimento, J.L.M., Alfonso, M,, \& Picanço-Diniz. C.W. (1997). Effects of methylmercury on the in Vivo release of dopamine and its acidic metabolites DOPAC and HVA from striatum of rats. Bulletin of Environmental Contamination and Toxicology, Ecotoxicology and Environmental Safety, 38, 95-98.

Faro, L.R.F., Nascimento, J.L.M., Alonso, M., \& Durán, R. (2002). Protection of methylmercury effects on the in vivo dopamine release by NMDA receptor antagonists and nitric oxide synthase inhibitors. Neuropharmacology, 42, 612-618.

Fjeld, E., Haugoen T.O., \& Vlestad, L.A. (1998). Permanent impairment in the feeding behavior of grayling (Thymallus Thymalus) exposed to methylmercury during embryogenesis. Science of the Total Environment, 213, 247-254.

Flood, N.C., Overmier, J.B., \& Savage, G.E. (1976). Teleost telencephalon and learning: an interpretive review of data and hypotheses. Physiology \& Behavior, 16, 783-788.

Fonfría, E., Rodríguez-Farré, E., \& Suñol, C. (2001). Mercury interaction with the $\mathrm{GABA}_{\mathrm{A}}$ receptor modulates benzodiazepine binding site in primary cultures of mouse cerebellar granule cells. Neuropharmacology, 41, 819-833.

Frankenhuis-van de Heuvel, T.H.M., \& Nieuwenhuys, R. (1984). Distribution of serotonin-immunoreactivity in the diencephalon and mesencephalon of the trout, Salmo gairdneri. Cellbodies, fibres and terminals. Anatomy \& Embriology, 169, 193-204.

Gassó, S., Suñol, C., Sanfeliu, C., Rodríguez-Farré, E., \& Cristòfol, R.M. (2000). Pharmacological characterization of the effects of methylmercury and mercuric chloride on spontaneous noradrenaline release from rat hippocampal slices. Life Sciences, 67, 1219-1231.

Girault L., Boudou, A. \& Dufourc, E.J. (1997). Methyl-mercury interactions with phospholipid membranes as reported by fluorescense, 31P and 199Hg NMR. Biochimica et Biophysica Acta, 1325, 250-262.

Gorlick, D.L. (1989). Motor inervation of respiratory muscles and an opercular display muscle in Siamese fighting fish Betta splendens. Journal of Comparative Neurology, 290, 412-422.

Graeff, F.G. (2002). On serotonin and experimental anxiety. Psychopharmacology (Berlim) 163, 467-476. 
Hare, M.F., \& Atchison, W.D. (1995a). Methylmercury mobilizes $\mathrm{Ca}^{++}$from intracellular stores sensitive to inositol 1,3,5triphosphate in NG108-15 cells. Journal of Pharmacology and Experimental Therapeutics, 272, 1016-1023.

Hare, M.F., \& Atchison, W.D. (1995b). Nifedipine and tetrodotoxin delay the onset of methylmercury-induced increase in $\left[\mathrm{Ca}^{2+}\right]_{\mathrm{i}}$ in NG108-15 cells. Toxicoogy and. Applied Pharmacoogy, 135, 299-307.

Harris, R.C., \& Bodaly, R.A. (1998). Temperature, growth and dietary effects on fish mercury dynamics on two Ontario lakes. Biogeochemistry, 40, 175-187.

Hartman, D.E. (1995). Neuropsychological toxicology: Identification and assessment of human neurotoxic syndromes ( $2^{\text {nd }}$ ed.). New York: Springer.

Hoffmeyer, R.E., Singh, S.P., Doonan, C.J., Ross, A.R., Hughes, R.J., Pickering, I.J., \& George, G.N. (2006). Molecular mimicry in mercury toxicology. Chemical Research in Toxicology, 19, 753-759.

Hrdina, P.D., Peters, D.A., \& Singhal, R.L. (1976). Effects of chronic exposure to cadmium, lead and mercury of brain biogenic amines in the rat. Research Communications in Biological Psychology and Psychiatry, 15, 483-493.

Juárez B.I., Portillo-Salazar, H., González-Amaro, R., Mandeville, P., Aguirre, J.R. \& Jiménez, M.E. (2005). Participation of Nmethyl-D-aspartate receptors on methylmercury-induced DNA damage in rat frontal cortex. Toxicology, 207, 223-229.

Juaréz, B. I., Portillo-Salazar, H., Gonzalez-Amaro, R., Mandeville, P., Aguirre, J. R., \& Jimenez, M. E. (2005). Participation of $\mathrm{N}$-methyl-D-aspartate receptors on methylmercury-induced DNA damage in rat frontal cortex. Toxicology, 207, 223-229.

Kapsimali, M., Vidal, B., Gonzalez, A., Dufour, S., \& Vernier, P. (2000). Distribution of the mRNA encoding the four dopamine D1 receptor subtypes in the brain of the european eel (Anguilla anguilla): Comparative approach to the function of D1 receptors in vertebrates. Journal of Comparative Neurology, 419, 320-343.

Kaur, P., Aschner, M., \& Syversen, T. (2006). Glutathione modulation influences methyl mercury induced neurotoxicity in primary cell cultures of neurons and astrocytes. Neurotoxicology, 4, 492-500.

Klein, R.M, Figler, M.H., \& Peeke, H.V.S. (1976). Modification of consummatory (attack) behavior resulting from prior habituation of appetitive (threat) components of the agonistic sequence in male Betta splendens (Pisces, Belontiidae). Behaviour, 58, 1-25.

Komulainen, H., \& Tuomisto, J. (1981). Interference of methylmercury with monoamine uptake and release in rat brain synaptosomes. Acta Pharmacologica et Toxicoogica, 48, 214222.

Kuo, T-C., Huang, C-L,, \& Lin-Shiau, S-Y. (2002). Methylmercury inhibits nitric oxide production mediated by $\mathrm{Ca}^{2+}$ overload and protein kinase A activation. Toxicology, 176, 113-122.

Fitzgerald, L.W., Kaplinsky, L., \& Kimelberg, H.K. (1990) Serotonin metabolism by monoamine oxidase in rat primary astrocyte cultures. Journal of Neurochemistry 55, 2008-2014.
Lesch, K.P., \& Merschdorf, U. (2000). Impulsivity, aggression, and serotonin: A molecular psychobiological perspective. Behavioral Sciences and the Law, 18, 581-604.

Ma, P. M. (1997). Catecholarminergic systems in the zebrafish. III. Journal of Comparative Neurology, 381, 411-427.

Marino-Neto, J., \& Sabbatini, R.M.E. (1983a). Neuroethological analysis of the effects of telencephalic lesions on aggressive behavior of Siamese fighting fish (Betta splendens). Proceedings of the $18^{\text {th }}$ Congress of the Sociedade Brasileira de Fisiologia, 470.

Marino-Neto, J., \& Sabbatini, R.M.E. (1983b). Discrete telencephalic lesions accelerate the habituation rate of behavioral arousal responses in Siamese fighting fish (Betta splendens). Brazilian Journal of Medical and Biological Research, 16, 271-278.

Marino-Neto, J., \& Sabbatini, R.M.E. (1988). A stereotaxic atlas for the telencephalon of the Siamese fighting fish (Betta splendens). Brazilian Journal of Medical and Biological Research, 21, 971-986.

McNaughton, N., \& Corr, P.J. (2004). A two-dimensional neuropsychology of defense: Fear/anxiety and defensive distance. Neuroscience and Biobehavioral Reviews, 28, 285-305.

Meek, J., Joosten, H.W.J., \& Hafmans, T.G.M. (2004). Distribution of noradrenaline-immunoreactivity in the brain of the mormyrid teleost Gnathonemus petersii. Journal of Comparative Neurology, 328, 145-160.

Meliska, C.J., Meliska, J.A., \& Peeke, H.V.S. (1980). Threat displays and combat aggression in Betta splendens following visual exposure to conspecifics and one-way mirrors. Behavioral and Neural Biology, 28, 473-486.

Meliska, J.A., \& Meliska, C.J. (1976). Effects of habituation on threat display and dominance establishment in the Siamese fighting fish, Betta splendens. Animal Learning \& Behavior, 4, 167-171.

Meliska, J.A., Meliska, C.J., Hoyenga, K.T., Hoyenga, K.B., \& Ward, E.F. (1975). Approach tendency and threat display as related to social status of Siamese fighting fish, Betta splendens. Animal Learning \& Behavior, 3, 135-139.

Miczek, K.A., Weerts, E., Vivian, J.A., \& Barros, H.M. (1995). Aggression, anxiety and vocalizations in animals: $\mathrm{GABA}_{\mathrm{A}}$ and 5-HT anxyolitics. Psychopharmacology, 121, 38-56.

Morken, T.S., Sonnewald, U., Aschner, M., \& Syversen, T. (2005). Effects of methylmercury on primary brain cells in mono- and co-culture. Toxicological Sciences, 87, 169-175.

Munro, A.D. (1986). The effects of apomorphine, d-amphetamine and chlorpromazine on the aggressiveness of isolated Aequidens pulcher (Teleostei, Cichlidae). Psychopharmacology, 88, 124128.

Nascimento, E.S., \& Chasin, A.A.M. (2001). Ecotoxicologia do Mercúrio e seus Compostos. Salvador, Brazil: Cadernos de Referência Ambiental v. 1

Ninomiya, T., Imamura, K., Kuwahata, M., Kindaichi, M.. Susa, M., \& Ekino, S. (2005). Reappraisal of somatosensory disorders in methylmercury poisoning. Neurotoxicology \& Teratology, 27, 643-653. 
Northcutt, R.G. (2006). Connections of the lateral and medial divisions of the goldfish telencephalic pallium. Journal of Comparative Neurology, 494, 903-943.

Ottoni, E.B. (2000). EthoLog 2.2: A tool for the transcription and timing of behavior observation sessions. Behavior Research Methods, Instruments, \& Computers, 32, 446-449.

Panksepp, J. (1998). Affective neurosciences. New York: Oxford. Portavella, M., Vargas, J.P., Torres, B., \& Salas, C. (2002). The effects of telencephalic pallial lesions on spatial, temporal and emotional learning in goldfish. Brain Research Bulletin, 57, 397-399

Regine, M.B., Gilles, D., Yannick, D., Alain, B. (2006). Mercury distribution in fish organs and food regimes: Significant relationships from twelve species collected in French Guiana (Amazonian basin). Science of the Total Environonment, 368, 262-270

Rhoad, K.D., Kalat, J.W., Klopfer, P.H. (1975). Aggression and avoidance by Betta splendens toward natural and artificial stimuli. Animal Learning \& Behavior, 3, 271-276.

Ritchie, T.C., Livingston, C.A.,, Hughes, M.G., McAdoo, D.J., \& Leonard, R.B. (1983). The distribution of serotonin in the CNS of an elasmobranch fish: Immunocytochemical and biochemical studies in the Atlantic stingray, Dasyatis sabina. Journal of Comparative Neuroology, 221, 429-443.

Roegge, C.S., Wang, V.C., Powers, B.E,, Klintsova, A.Y., Villareal, S., Greenough, W..T, \& Schantz, S.L. (2004). Motor impairment in rats exposed to PCBs and methylmercury during early development. Toxicological Sciences, 77, 315-324.

Royalty, J., Taylor, G.T., Korol, B.A. (1987). The effects of prenatal exposure to methylmercury on aggressive behavior in the rat. Neurotoxicology \& Teratology, 9, 87-93.

Scheuhammer, A.M., \& Cherian, M.G. (1985). Effects of heavy metal cations sulfhydryl reagents and other chemical agents on striatal $\mathrm{D}_{2}$ dopamine receptors. Biochememical Pharmacology, 34, 3405-3413.

Setini, A., Pierucci, F.., Senatori, O., \& Nicotra, A. (2005). Molecular characterization of monoamine oxidase in zebrafish (Danio rerio). Comparative Biochemistry \& Physiology. Part B Biochemistry \& Molecular Biology, 140, 153-161.
Simpson, M.J.A. (1968). The display of the Siamese fighting fish, Betta splendens. Animal Behavior Monographs, 1, 1-73.

Smith, G.M., \& Weis, J.S. (1997). Predator-prey relationships in mummichogs (Fundulus heteroclitus [L.]): Effects of living in a polluted environment. Journal of Experimental Marine Biology and Ecology, 209, 75-87.

Tarabova, B., Kurejova, M., Sulova, Z., Drabova, M., \& Lacinova, L. (2006). Inorganic mercury and methylmercury inhibit the Cav3.1 channel expressed in human embryonic kidney 293 cells by different mechanisms. Journal of Pharmacology and Experimental Therapeutics, 317, 418-427.

Webber, H.W., \& Haines, T.A. (2003). Mercury effects on predatory avoidance behavior of a forage fish, Golden shiner (Notemigus crysoleucas). Environmental Toxicology and Chemistry, 22, 1556-1561.

Weis, J.S., Smith, G., Zhou, T., Santiago-Bass, C., \& Weis, P. (2001). Effects of contaminants on behavior: Biochemical mechanisms and ecological consequences. BioScience, 51, 209-217.

Westlund, K.N., Denney, R.M,, Kochersperger, L.M., Rose, R.M., \& Abell, C.W. (1985). Distinct monoamine oxidase A and B populations in primate brain. Science, 11, 181-183.

Woebser, G. (1975). Acute toxicity of methylmercury chloride and mercuric chloride for rainbow trout (Salmo gairdneri) fry and fingerlings. Journal of the Fisheries Research Board of Canada, 32, 2005-2013.

Yasutake, A., Nakano, A., Miyamoto, K., \& Eto, K. (1997). Chronic effects of methylmercury in rats. I. Biochemical aspects. Tohoku Journal of Experimental Medicine, 3, 185-196.

Yee, S., \& Choi, B.H. (1994). Methylmercury poisoning induces oxidative stress in the mouse brain. Experimental \& Molecular Pathology, 60, 188-196.

Yuan, Y., Otero-Montañez, J.K.L., Yao, A., Herden, C.J., Sirois, J.E., \& Atchison, W.D. (2005). Inward rectifying and voltagegated outward potassium channels exhibit low sensitivity to methylmercury. Neurotoxicology, 26, 439-454.

Received June, 12, 2006

Revision received January, 8, 2007

Accepted March, 28, 2007 